\title{
Frequency of hypertension, age, and gender in cerebrovascular disease in Paraguay
}

\author{
Luis Díaz-Escobar, Alan Flores*, Laia Seró-Ballesteros, Christian Otto, Ricardo Mernes, Fátima Pedrozo, \\ Fabiola Riquelme, Romina González and Silvia González \\ Unidad de Ictus, Hospital de Clínicas, Servicio de Urgencias, Facultad de Ciencias Médicas, Universidad Nacional de Asunción. San Lorenzo, Paraguay
}

\begin{abstract}
Background: Hypertension, age, and gender are relevant factors associated to cerebrovascular disease. In Paraguay, cerebrovascular disease is the fourth cause of mortality; however, information about demographic and baseline characteristics are not widely knowledge. Our aim was to determinate the prevalence of hypertension, age, and gender in the setting of acute phase stroke in our population. Methods: This is a descriptive, single-center study. Data were collected from a prospective registry of stroke patients admitted in the stroke unit of our center, from April 2015 to December 2016. Results: From 996 stroke patients, 252 (25.3\%) presented intracerebral hemorrhage (ICH). 390 (39.1\%) were female. The hypertension rate was $74 \%$ and $78 \%$ in ischemic stroke and $\mathrm{ICH}$, respectively, being hypertensive hemorrhagic etiology, $79.5 \%$ of the $\mathrm{ICH}$ and lacunar infarct $11.6 \%$ of ischemic strokes. In ICH patients, mean age differences between genders were remarkable (mean years 55.41 [standard deviation (SD) \pm 14.8 ] vs. 62.48 $[S D \pm 15.2], p \leq 0.001)$. In the multivariate analysis, lower age than 60 years old (odds ratio [OR]: 4.893; confidence interval [CI] 95\%: 1.772-13.509, $p=0.029$ ) and higher systolic blood pressure at admission (OR: 1.098; Cl 95\% 1.044-1.155, $p=0.009$ ) were independent factors associated to $\mathrm{ICH}$. Conclusion: In our population, $\mathrm{ICH}$ rates are similar to regional findings, occurring an early age than other series, being remarkable in males. Hypertension rates in ischemic stroke and ICH are higher than other series and the variability of presumed hypertensive microangiopathy phenotype could be in relation to age (hypertensive hemorrhage vs. lacunar). These findings would be related to ethnic, social, environment, and geographic factors.
\end{abstract}

Key words: Stroke epidemiology. Hypertensive hemorrhage. Female stroke. Vascular risk factors. Intracerebral hemorrhage.

\section{Frecuencia de la hipertensión, edad y género en la enfermedad cerebrovascular en Paraguay}

\section{Resumen}

Resumen: La hipertensión, la edad y el género son factores relevantes asociados a enfermedad cerebrovascular(ECV). En Paraguay, la ECV es la cuarta causa de mortalidad, sin embargo, información sobre sus características no son de amplio conocimiento. Nuestro objetivo fue determinar la frecuencia de la hipertensión, la edad, el género en la ECV en fase aguda en

\footnotetext{
Correspondence:

${ }^{\star}$ Alan Flores

Unidad de Ictus, Hospital de Clínicas

Facultad de Ciencias Médicas

Universidad Nacional de Asunción_ Date of reception: 19-09-2017

San Lorenzo, Paraguay_ Date of acceptance: 22-04-2019

E-mail: alanflo2507@ hotmail.com

DOI: 10.24875/RMN.M19000042

Available online: 18-06-2019 Rev Mex Neuroci. 2019;20(3):130-135 www.revmexneurociencia.com 1665-5044/@ 2019. Academia Mexicana de Neurología A.C. Published by Permanyer México. This is an Open Access article under the terms of the CC BYNC-ND license (http://creativecommons.org/licenses/by-nc-nd/4.0/).
} 
nuestra población. Métodos: Se trata de un estudio observacional descriptivo monocéntrico. Se recogieron datos de un registro prospectivo de pacientes con ictus ingresados en la Unidad de Ictus de nuestro centro, desde abril del 2015 a marzo de 2019. Resultados: De 996 pacientes con ictus, 252(25,3\%) presentaron hemorragia intracerebral (HIC). Trescientos noventa (39.1\%) fueron mujeres. La tasa de hipertensión arterial fue elevada en isquémicos(74\%) como hemorrágicos(78\%), siendo la hemorragia hipertensiva el $79.5 \%$ de las HIC y los lacunares el $11.6 \%$ de ictus isquémicos. En pacientes con HIC, la diferencia de edad entre géneros fue significativa (media/años 55.41 (SD \pm 14.8 ) Vs 62.48 (SD \pm 15.2 ) $p=<0.001$ ). En el análisis multivariante fueron factores independientes asociados a HIC una edad menor a 60 años (OR: 4.893;IC95\%:1,772-13,509p=0.029) y una elevada presión arterial sistólica al ingreso(OR:1.098;/C95\%1,044-1,155,p=0.009). Conclusión: En nuestra población, la frecuencia de HIC es similar a lo descrito en la región, observándose una edad más temprana que otras series, siendo remarcable en el género masculino. La tasa de hipertensión en HIC e ictus isquémico es mayor que en otras series y la variación de distintos fenotipos por presunta microangiopatía hipertensiva estaría relacionado en parte a la edad (hemorragia hipertensiva Vs. lacunares). Estos resultados podrían explicarse por razones étnicas, socio-ambientales y geográficas.

Palabras Clave: Ictus epidemiología. Hemorragia cerebral hipertensiva. Ictus en la mujer. Factores de riesgo. Hemorragia intracerebral.

\section{Introduction}

Stroke is one of the diseases with the greatest impact on public health, being the third cause of mortality and leading cause of disability in the western world since most patients suffer sequels, which in $30 \%$ of cases disable them to perform daily activities ${ }^{1,2}$.

The proportion and frequency between the ischemic types and intracerebral hemorrhage $(\mathrm{ICH})$ are variables according to a determined region; while in Spain, the rates of $\mathrm{ICH}$ are around to $12 \%{ }^{3}$, in regions of South America such as Ecuador and Chile, the $\mathrm{ICH}$ reach rates between 37 and $46 \%{ }^{4}$. In Paraguay, cerebrovascular disease is the fourth cause of death ${ }^{5}$. However, other data about the baseline characteristics in our population are not widely known.

Among the cardiovascular risk factors related to stroke, hypertension is the most frequent and important risk factor. The prevalence is around $70 \%$ in both ischemic and hemorrhagic patients and its optimal control is possibly one of the most important interventions in secondary prevention for both types of stroke ${ }^{3,6}$. In Paraguay, the prevalence of hypertension is high, with rates of $53 \%$ in men and $40 \%$ in women between 35 and 45 years, reaching up to $81 \%$ in the general population between 65 and 74 years ${ }^{7}$.

Another known and controversial stroke risk factor is gender and their disparities in baseline and clinical outcomes. Several descriptive studies have shown an association of older age, frequency of hypertension, obesity, and atrial fibrillation in women than in $\operatorname{men}^{8,9}$.

\section{Objective}

The objective of this study was to determine the rates of hypertension, age, gender, and other known risk factors in patients with stroke in the acute phase in our environment.

\section{Methods}

This is a descriptive, observational study in a single center. Data were collected from a prospective of stroke patients admitted in the Stroke Unit of our center since April 2015-March 2019.

The known modifiable and non-modifiable risk factors have been recorded. In patients with hemorrhagic stroke, the etiology of hypertensive ICH has been determined according to the history of hypertension, the topography of the parenchymal lesion, and the vascular study ${ }^{10}$. The diagnosis of ischemic stroke was made according to the criteria of the Oxfordshire Community Stroke Project and the Trial of Org 10172 in acute stroke treatment ${ }^{11}$.

The descriptive statistical analysis was performed for all the parameters, which included measurements of the central tendency and dispersion for the quantitative variables, as well as absolute and relative frequencies for the qualitative variables, with their $95 \%$ confidence interval $(\mathrm{Cl})$ in both cases. If the data did not meet the assumptions of normality for the analysis, non-parametric statistical methods were used (Student's t-test or Mann-Whitney U-test, respectively). The Chi-square test was applied for the comparison between the proportions. To determine the weight of each of the risk factors between ischemic and hemorrhagic stroke, multiple logistic regression models were established, with a $95 \% \mathrm{Cl}$. The statistical tests were performed with a significance level of $5 \%$. The statistical program SPSS v. 23.0 was used to perform the analysis. 
Table 1. Baseline characteristics of all patients with stroke and subgroups, ischemic and hemorrhagic with their significance in the univariate analysis

\begin{tabular}{|l|c|c|c|c|}
\hline & $\begin{array}{c}\text { All } \\
(\mathbf{n = 9 9 6 )}\end{array}$ & $\begin{array}{c}\text { Ischemic } \\
(\mathbf{n = 7 4 4 )}\end{array}$ & $\begin{array}{c}\text { ICH } \\
\text { (n= 252) }\end{array}$ & p value \\
\hline Age, year & $62.8 \mathrm{DS} \pm 15.3$ & $64.3 \mathrm{DS} \pm 15.2$ & $58.1 \pm 14.8$ & $<0.001$ \\
\hline Glycemia at admission mgr/dl. (n: 169) & $165.4 \mathrm{DS} \pm 120.3$ & $168.6 \mathrm{DS} \pm 97.7$ & $155.9 \mathrm{DS} \pm 120.3$ & 0.513 \\
\hline Female gender $\mathrm{n}(\%)$ & $390(39.1)$ & $295(39.6)$ & $93(36.9)$ & 0.585 \\
\hline Hypertension $\mathrm{n}(\%)$ & $749(75.2)$ & $553(74.3)$ & $195(77.3)$ & 0.102 \\
\hline Diabetes mellitus $\mathrm{n}(\%)$ & $237(23.6)$ & $206(23.5)$ & $30(3.4)$ & $9(1)$ \\
\hline Dyslipidemia $\mathrm{n}(\%)$ & $56(5.6)$ & $47(5.4)$ & $11(1.3)$ & 0.144 \\
\hline Atrial fibrillation & $128(12.7)$ & $117(13.6)$ & $10(1.0)$ & $<0.001$ \\
\hline Prior antiplatelet treatment & $996(99.1)$ & $81(8.1)$ & $21(2.5)$ & 0.003 \\
\hline Prior stroke & $150(14.9)$ & $129(15.4)$ & $9(4)$ & 0.001 \\
\hline Baseline NIHSS median (interquartile range) & $8(4)$ & $8(4)$ & $189.9 \pm 43.2$ & 0.796 \\
\hline Systolic blood pressure at admission & $169.8 \pm 38.3$ & $161.4 \pm 32.5$ & 0.001 \\
\hline
\end{tabular}

\section{Results}

From 996 patients with stroke, $744(74.7 \%)$ were ischemic and $252(25.3 \%) \mathrm{ICH}, 390$ (39.1\%) were women. The mean age was 62.8 years (standard deviation $[S D] \pm 15.3$ ). From overall, $75.4 \%$ had known antecedent of hypertension, $27 \%$ diabetes mellitus (DM), and $6.4 \%$ dyslipidemia. The median baseline NIHSS was 8 (interquartile range [IQR]: 4-12). The baseline characteristics in general and of the ischemic and hemorrhagic groups are shown in Table 1.

In ischemic stroke patients, the mean age was 64.3 (SD \pm 15.2 ) years, the median of NIHSS 8 (IQR 4-12), and $39.8 \%$ were women. Patients with ischemic stroke were significantly older (mean years $64.3 \mathrm{SD} \pm 15.2$ vs. $58.1 \mathrm{SD} \pm 14.8$ ), had higher glycemia at admission (mean mgr./dl 168.6 SD \pm 97.7 vs. $155.9 \mathrm{SD} \pm 120.3$, $p=0.513)$, frequency of DM $(23.5 \%$ vs. $3.4 \%, p=0.001)$, atrial fibrillation ( $13.6 \%$ vs. $1.3 \%, p=0.001$ ), prior history of stroke ( $15.4 \%$ vs. $2.5 \%, p=0.001)$, prior antiplatelet treatment $(8.1 \%$ vs. $1.0 \%, p=0.001)$, and lower systolic blood pressure on arrival than patients with $\mathrm{ICH}$ (mean $\mathrm{mmHg}, 169.8 \mathrm{SD} \pm 38.3$ vs. $189.9 \mathrm{SD} \pm 43.2$ ).

The most frequent etiology were (422 cases work-up performed) cardioembolic $41.2 \%$, indeterminate in $24.1 \%$, lacunar infarcts in $11.6 \%$, and atherothrombotic in $21.5 \%$. Hypertension was present in $91 \%$ of atherothrombotic strokes, $89.6 \%$ of lacunar strokes, $80.8 \%$ in cardioembolic, and $77.6 \%$ of indeterminate strokes, Figure 1.

$\mathrm{ICH}$ patients had a mean age of 58.1 (SD \pm 14.8 ) years, the median of NIHSS was 9 (IQR 5-13), and
$36.9 \%$ were women. From 142 cases with etiological work-up, $79.5 \%$ were due to hypertensive hemorrhage. The factors significantly related to hypertensive hemorrhage (113 cases evaluated) were hypertension ( $p \leq 0.001)$ and the lower age stratified by groups $(p=0.006)$, Figure 2 .

In the multivariate analysis adjusted for sex, hypertension, DM, previous stroke, and atrial fibrillation, age $<60$ years old (odds ratio [OR]: $4.893,95 \%$ Cl: $1.772-$ $13.509, p=0.029)$ and a higher systolic blood pressure at admission (OR: $1.098,95 \% \mathrm{Cl} 1.044-1.155, \mathrm{p}=0.009$ ) were independent factors associated with $\mathrm{ICH}$.

In relation to gender, hypertension was present in $79.3 \%$ in men and $83.5 \%$ in women. In men, smoking habit was significantly more frequent $(23.9 \%$ vs. $3.4 \%$, $p<0.001)$ and they presented more ischemic heart disease $(7.9 \%$ vs. $2.3 \%, p=0.001)$ than women. Men were younger (61.75 $\mathrm{SD} \pm 13.6$ vs. $64.16 \mathrm{SD} \pm 17.4$, $\mathrm{p}=0.003$ ), being in the $\mathrm{ICH}$ group, even more remarkable the difference (mean years 55.41 [SD \pm 14.8 ] vs. 62.48 [SD \pm 15.2$], p \leq 0.001$ ), Figure 3 .

\section{Discussion}

This is a descriptive study, with data from a prospective cohort over a period of 41 months. In general, there is a higher proportion of men than women with stroke, and the mean age is significantly lower than in developed countries ${ }^{1,3}$, but similar to the previous studies in Buenos Aires and Brasilia ${ }^{12,13}$. Hypertension is the most frequent risk factor, slightly higher than other series 3,12-14. 


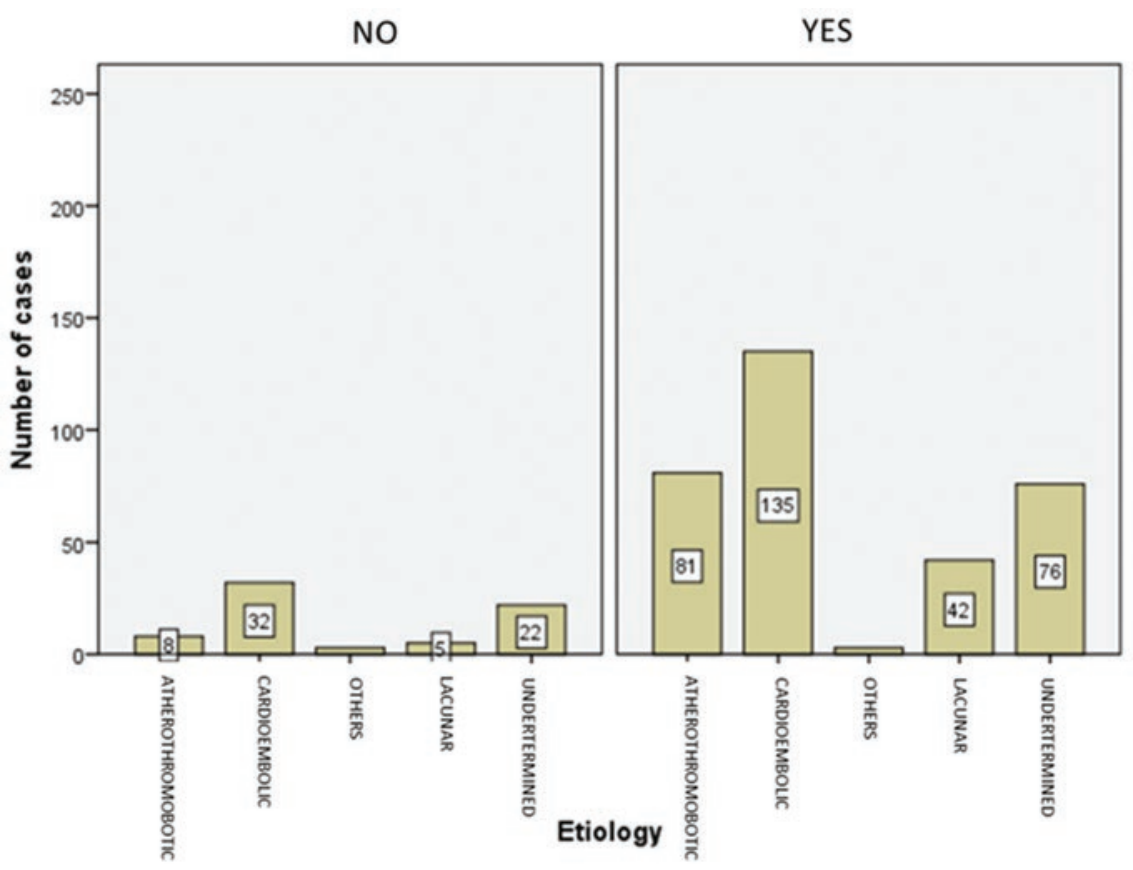

Figure 1. Graphic bar showing number of cases of ischemic stroke etiology according to prior hypertension status.

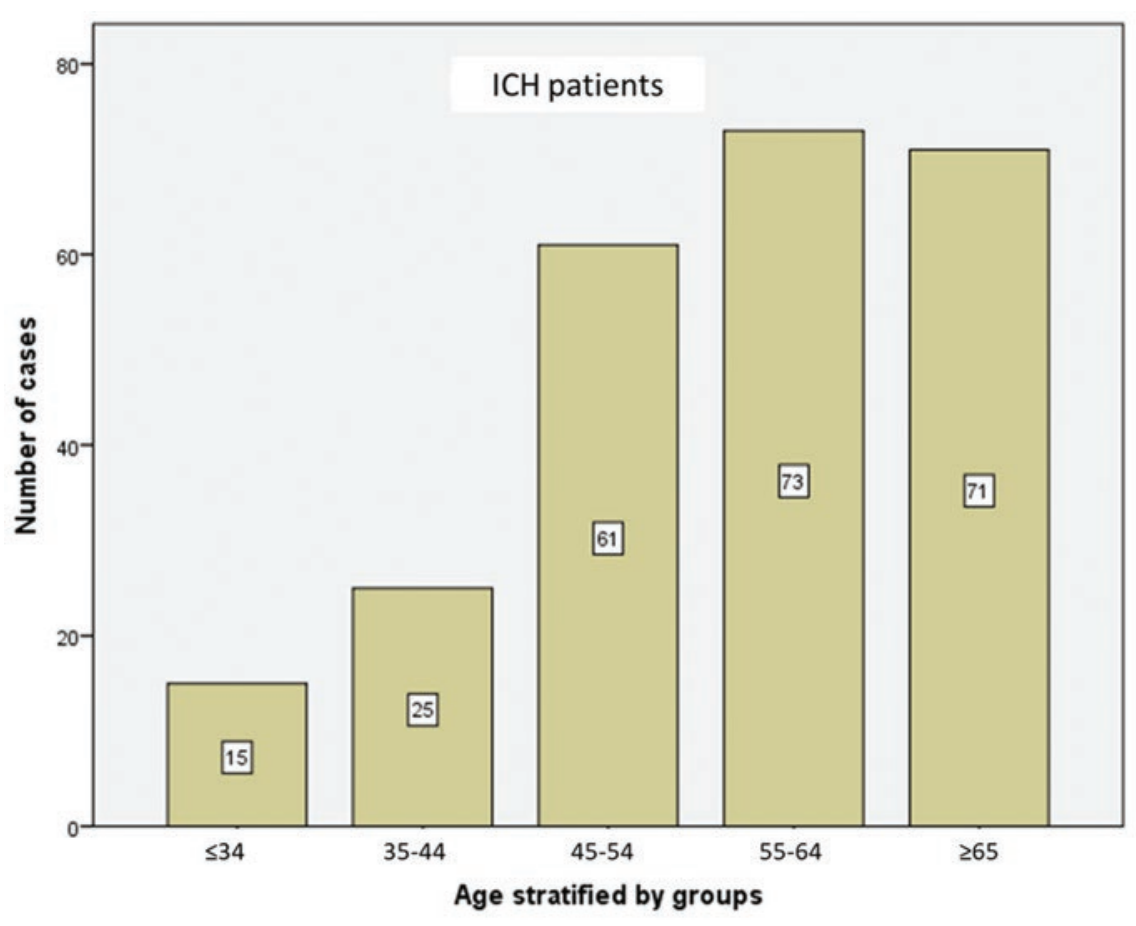

Figure 2. Graphic bar showing number of cases of intracerebral hemorrhage according to stratified age group.

Another risk factors rate such as DM, previous stroke, and atrial fibrillation was similar to prior studies; however, the frequency of dyslipidemia, known ischemic cardiopathy, and smoking was strikingly lower ${ }^{3,12-14}$. Possible explanations (in addition to the inherent biases and limitations from the nature of this study) are that our 


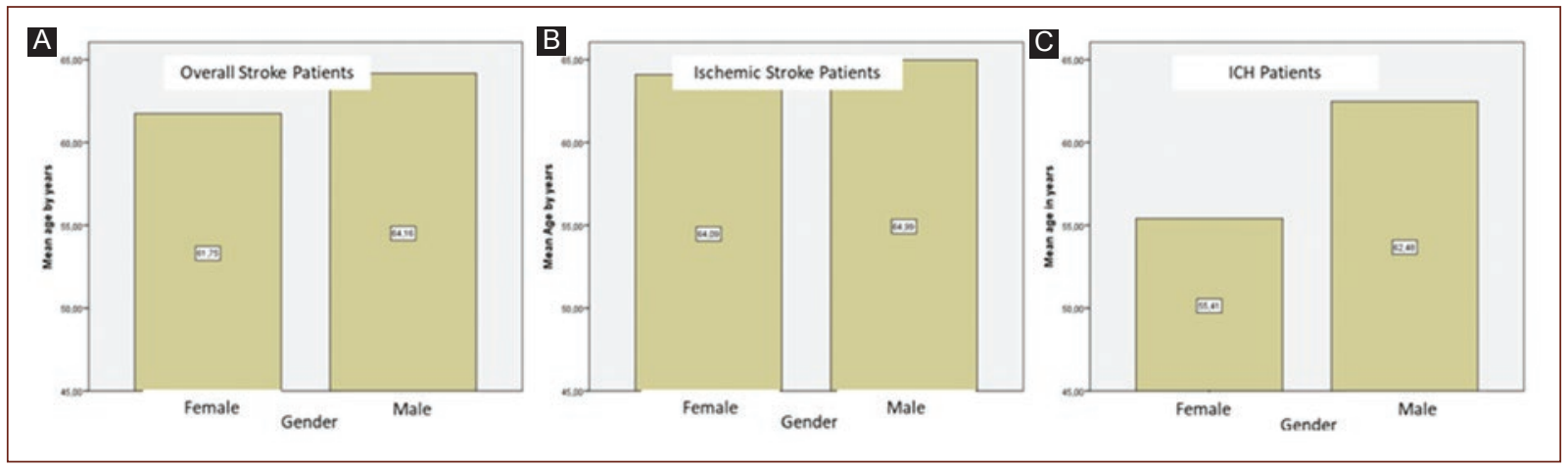

Figure 3. Bars showing the mean age according to gender in overall (A), ischemic (B), and intracerebral hemorrhage (C) stroke patients.

center, although it is located in an urban center, is a reference center that receives patients from the rural area also, and this could affect our results. Another reason would be the lack of knowledge of the risk factors of our population (less than half of men know about their blood cholesterol levels ${ }^{7}$ ).

The rate of HIC is significantly higher than that described in developed countries ${ }^{3,12}$ and is consistent with results from our region in studies conducted in Chile, Ecuador, and Argentina ${ }^{14-16}$. These results are explained by the high prevalence rate of hypertension in our population, especially manifests at early ages in the adult?

In relation to ischemic stroke, the etiology by TOAST (in 422 cases) showed a high rate of cardioembolic $(41.2 \%)$, however, a lower frequency of atheromatous disease $(21.5 \%)$ and lacunar (11.6\%). These results are more similar with those found in Santiago ${ }^{14}$ than in those shown in Brasilia, Guayaquil, and Buenos Aires $^{13,15,16}$. It should be noted that in South America, the frequency in relation to the etiology of stroke is very heterogeneous and diverse, mainly due to ethnic, geographical, and sociocultural differences ${ }^{4}$. Finally, the relative high rate of indeterminate etiology would be related in many cases to an incomplete study and is a clear limitation at the present study.

Interestingly, while hypertension rates are high $(79.3 \%)$ in ischemic patients, the percentage of lacunar strokes for presumed hypertensive microangiopathy as a cause is lower than expected (11.6\%). In contrast, hypertensive hemorrhage represents the cause of up to $79.5 \%$ of $\mathrm{ICH}$. The previous studies in relation to this possible common substrate have shown that the cerebral vascular phenotype (ICH vs. lacunar infarcts) due to hypertensive microangiopathy would be related in part to age and cholesterol levels ${ }^{17,18}$. Therefore, a possible explanation to our findings could be related to age (remarkably younger patients) and the lower frequency of dyslipidemia (5.6\%) known in our population. Another possible explanation would be in relation to the less severe clinical deficit associated with lacunar stroke ${ }^{19}$, which may affect the arrival or referral of these patients. These results are consistent in the region with the previous studies in Santiago de Chile and Bogotá13,20. Unfortunately, the body mass index, which has been shown to be a prognostic factor for the development of $\mathrm{ICH}$ or lacunar infarctions in hypertensive microangiopathy ${ }^{18}$, has not been evaluated in the present study. Future prospective and comparative studies should be taken into account to confirm these findings.

Regarding gender, women presented a stroke less frequently, with greater age (according to literature ${ }^{8,21,22}$ ) and significantly less known cardiovascular risk factors than men, which is also consistent with the previous studies. Factors such as hypertension and atrial fibrillation, which in other series showed a significantly higher frequency in women, have not been seen in our study 8,9 . The age difference in HIC is remarkable among genders, being the higher hypertension prevalence in early $\mathrm{age}^{7}$ and the hypothetical hormonal preventive effect in women ${ }^{20,21}$ probable reasons of this finding.

As a relevant limitation at the present study, it is a monocentric study, involving patients from urban and rural areas that may not represent a specific geographic area.

In this prospective study in our country, hypertension is a risk factor highly related to stroke with a higher frequency of hypertensive hemorrhages in younger patients than other series, especially in men. The frequency of different stroke subtypes would be related to environmental, sociocultural, and biological factors. Multicenter and comparative studies are warranted to confirm these findings. The intensification of public health programs focused on the control of risk factors, 
especially hypertension, is necessary to prevent cerebrovascular disease in our environment.

\section{Funding}

There was no particular funding source for this scientific report.

\section{Conflicts of interest}

The authors declare that in this study, there are no relevant conflicts of interest.

\section{References}

1. Bonita R. Epidemiology of stroke. Lancet. 1992;339:342-4.

2. Truelsen T, Piechowski-Jó区wiak B, Bonita R, Mathers C, Bogousslavsky J, Boysen G, et al. Stroke incidence and prevalence in Europe: a review of available data. Eur J Neurol. 2006;13:581-98.

3. Arias-Rivas S, Vivancos-Mora J, Castillo J, En Nombre de Los Investigadores Del Registro Epices. Epidemiology of the subtypes of stroke in hospitalised patients attended by neurologists: results of the EPICES registry (I). Rev Neurol. 2012;54:385-93.

4. Saposnik G, Brutto OH, Iberoamerican Society of Cerebrovascular Diseases. Stroke in South America: a systematic review of incidence, prevalence, and stroke subtypes. Stroke. 2003;34:2103-7.

5. Boletín de Vigilancia. Enfermedades no Transmisibles y Factores de Riesgo. Ministerio de Salud Pública y Bienestar Social; 2015. Available from: http://www.mspbs.gov.py.

6. Kernan WN, Ovbiagele B, Black HR, Bravata DM, Chimowitz MI, Ezekowitz MD, et al. Guidelines for the prevention of stroke in patients with stroke and transient ischemic attack: a guideline for healthcare professionals from the American heart association/American stroke association. Stroke. 2014;45:2160-236.

7. Primera Encuesta Nacional de Factores de Riesgo de Enfermedades No Transmisibles. Primera Edición. Asunción, Ministerio de Salud Pública y Bienestar Social; 2012. Available from: http://www.mspbs.gov.py.
8. Andersen KK, Andersen ZJ, Olsen TS. Age and gender-specific prevalence of cardiovascular risk factors in 40,102 patients with first-ever ischemic stroke: a nationwide Danish study. Stroke. 2010;41:2768-74.

9. Reeves MJ, Bushnell CD, Howard G, Gargano JW, Duncan PW, Lynch $\mathrm{G}$, et al. Sex differences in stroke: epidemiology, clinical presentation, medical care, and outcomes. Lancet Neurol. 2008;7:915-26.

10. Lang EW, Ya ZR, Preul C, Hugo HH, Hempelmann RG, Buhl R, et al. Stroke pattern interpretation: the variability of hypertensive versus amyloid angiopathy hemorrhage. Cerebrovasc Dis. 2001;12:121-30.

11. Bamford J, Sandercock P, Dennis M, Burn J, Warlow C. Classification and natural history of clinically identifiable subtypes of cerebral infarction. Lancet. 1991;337:1521-6.

12. Saposnik G, Caplan LR, Gonzalez LA, Baird A, Dashe J, Luraschi A, et al. Differences in stroke subtypes among natives and Caucasians in Boston and Buenos Aires. Stroke. 2000;31:2385-9.

13. Carod-Artal FJ, Lanchipa JO, Ramírez LM, Pérez NS, Aguayo FM, Moreno IG, et al. Stroke subtypes and comorbidity among ischemic stroke patients in Brasilia and cuenca: a Brazilian-Spanish cross-cultural study. J Stroke Cerebrovasc Dis. 2014:23:140-7.

14. Nogales-Gaete J, Núñez L, Arriagada C, Sáez D, Figueroa T, Fernández R, et al. Caracterización clínica de 450 pacientes con enfermedad cerebrovascular ingresados a un hospital público durante 1997. Rev Med Chil. 2000;128:1227-36.

15. Del Brutto $\mathrm{OH}$, Mosquera A, Sánchez X, Santos J, Noboa CA. Stroke subtypes among hispanics living in Guayaquil, ecuador. Results from the Luis Vernaza hospital stroke registry. Stroke. 1993;24:1833-6.

16. Saposnik G, Gonzalez L, Lepera S, Luraschi A, Sica RE, Caplan LR, et al. Southern buenos aires stroke project. Acta Neurol Scand. 2001;104:130-5.

17. Labovitz DL, Boden-Albala B, Hauser WA, Sacco RL. Lacunar infarct or deep intracerebral hemorrhage: who gets which? The northern Manhattan study. Neurology. 2007;68:606-8.

18. Lioutas VA, Beiser A, Himali J, Aparicio H, Romero JR, DeCarli C, et al. Lacunar infarcts and intracerebral hemorrhage differences: a nested case-control analysis in the FHS (Framingham heart study). Stroke. 2017; 48:486-9.

19. Pantoni L. Cerebral small vessel disease: from pathogenesis and clinical characteristics to therapeutic challenges. Lancet Neurol. 2010;9:689-701.

20. Peña I, Ruiz C, Morillo LE, Pedraza OL, Sánchez E, Santín LC, et al. Clasificación del TOAST en la práctica clínica de un hospital universitario. Acta Neurol Colombiana. 2001;17:304-30.

21. Alonso de Leciñana M, Egido JA, Fernández C, Martínez-Vila E, Santos $\mathrm{S}$, Morales $\mathrm{A}$, et al. Risk of ischemic stroke and lifetime estrogen exposure. Neurology. 2007;68:33-8.

22. Murphy SJ, McCullough LD, Smith JM. Stroke in the female: role of biological sex and estrogen. ILAR J. 2004;45:147-59. 